\title{
Physico-mechanical properties of cattle hide leather for working gloves with flame retardant addition
}

\author{
Iwan Fajar Pahlawan *, Gresy Griyanitasari \\ Center for Leather, Rubber and Plastics, Ministry of Industry, Yogyakarta 55166 \\ *Correspondence: iwan.fp@kemenperin.go.id \\ Received: February 1'st 2020; Accepted: May 29th, 2020 ; Published online: July 17th 2020
}

Abstrak

Tujuan: Industri pengecoran logam merupakan industri padat karya yang melibatkan penggunaan panas di tempat kerja. Oleh karena itu, suatu hal yang penting untuk melindungi pekerja dari segala resiko selama beraktivitas. Sarung tangan kulit, sebagai alat pelindung diri, harus dibuat agar dapat mencegah pekerja mengalami luka bakar. Penelitian ini bertujuan untuk menganalisis pengaruh penggunaan bahan tahan api terhadap sifat fisis dan mekanis bahan kulit jadi untuk artikel tertentu, yaitu sarung tangan kerja.

Metode: Penelitian ini menggunakan kulit sapi pikel dan bahan tahan api komersial sebagai bahan utama. Bahan kimia kulit yang digunakan dalam proses adalah bahan yang umum digunakan untuk membuat artikel bahan kulit untuk sarung tangan kerja. Perlakuan dalam penelitian merupakan penambahan bahan tahan api komersial dalam proses peminyakan $(2 \%, 4 \%, 6 \% \mathrm{~b} / \mathrm{b})$ dan finishing (100 bagian, 200 bagian, 300 bagian). Pengaruh penambahan bahan kulit terhadap persentase pengerutan, ketebalan, ketahan gosok, kekuatan tarik, dan kemuluran, dievaluasi. Analisa deskriptif digunakan untuk menggambarkan sifat-sifat yang dievaluasi dari bahan kulit jadi yang dihasilkan.

Hasil: Hasil penelitian menunjukkan bahwa penambahan bahan tahan api dalam proses peminyakan dan finishing menghasilkan bahan kulit untuk sarung tangn kerja dengan sifat fisis-mekanis yang bervariasi. Bahan kulit, dengan penambahan bahan tahan api sebanyak $4 \%(\mathrm{~b} / \mathrm{b})$, memiliki nilai kekuatan tarik $520.48 \pm 13.79 \mathrm{~kg} / \mathrm{cm}^{2}$, penyusutan sebesar $7.65 \pm 1.42 \%$, ketahan gosok yang baik (5 dan 4/5), dan nilai kemuluran $(52.9 \pm 4.09 \%)$ serta ketebalan $(0.87 \pm 0.02 \mathrm{~mm})$.

Kesimpulan: Disimpulkan bahwa penggunaan bahan tahan api sebanyak $4 \%$ (b/b) dalam proses peminyakan dianggap sebagai formulasi terbaik untuk menghasilkan bahan kulit untuk sarung tangan kerja.

Kata Kunci: Bahan kulit untuk sarung tangan; Bahan tahan api; Kulit sapi; Proses finishing; Proses peminyakan; Sifat fisis-mekanis

\begin{abstract}
Objective: Indonesian metal casting industry is a labor-oriented industry which involves thermal application in the workplace. Thus, it is essential to protect the workers for any risks during their activity. Leather gloves, as personal protective equipment, need to be manufactured that can prevent the workers from burn injured. The study aimed to analyze the effect of flame retardant addition on finished leather's physical and mechanical properties for a specific article, i.e. working gloves.

Methods: The research used pickled cattle hides and commercial flame retardant as main materials. The leather chemicals used in the process are those which is commonly used to manufacture
\end{abstract}


working gloves leather article. The treatments involved the addition of commercial flame retardant in fatliquoring $(2 \%, 4 \%, 6 \% \mathrm{w} / \mathrm{w})$ and finishing process (100 parts, 200 parts, 300 parts). The effect of flame retardant addition on shrinkage percentage, thickness, rub fastness, tensile strength, and elongation at break, were evaluated. Descriptive analysis is applied to describe the properties of the resulted finished leather.

Results: The result shows that the addition of flame retardant in fatliquoring and finishing process indicates a variation in the leather's physical-mechanical properties. The leather, manufactured with the addition of $4 \%(\mathrm{w} / \mathrm{w})$ in fatliquoring, shrunk $7.65 \pm 1.42 \%$, had tensile strength value at $520.48 \pm 13.79 \mathrm{~kg} / \mathrm{cm}^{2}$, good rub fastness at dry and wet basis (5 and 4/5), elongation value at $52.9 \pm 4.09 \%$, and thickness $0.87 \pm 0.02 \mathrm{~mm}$.

Conclusions: it can be concluded that the use of $4 \%(\mathrm{w} / \mathrm{w})$ flame retardant in fatliquoring is suggested to be the best formulation to produce working gloves leather.

Keywords: Cattle hide; Fatliquoring; Flame retardant; Finishing process; Working gloves leather; Physico-mechanical property

\section{INTRODUCTION}

The animal industry is a developed industry in the world, which covers a wide range of products from upstream to downstream. The upstream activity involves many activities to provide a good quality livestock supply, thus it influences the quality of the downstream activity. One of the downstream activities is processing animal by-products to create a value of the product. Hide or skin is a left-over product from a meat industry, where taken from slaughterhouses. As a result, hides or skins are discarded and are not sent to meat processing plants. Nowadays, hides or skins are a valuable commodity due to the demand for it. Hides or skins have been transformed into luxurious goods with a touch of technology. According to the Indonesian Ministry of Trade, Indonesia had sent out raw hides, skins, and leather worth up to 833 million USD to the global market in 2018. Meanwhile, the export value of the leather articles in 2018 worthed 5,958 million USD. There was a positive trend in the export of leather articles, while the export of raw hides, skins, and leather was in a negative trend, during 2014 - 2018 (Ministry of Trade, 2019). It shows that the Indonesian leather and leather goods manufacturers have successfully manufactured a good quality leather article that can be accepted in the global market.

Hide or skin is categorized as a natural fiber that could be changed into a unique material, namely leather, which is included in a biomaterial. Its degradability properties and its nature against microorganisms could be transformed into leather which has advantages related to external conditions with tanning technology. There are plenty of goods have been manufactured from leather, such as footwear, garment, wallet, luggage, belt, as well as gloves. Gloves have been widely used in industrial activities as part of protection for labors. Dianat et al. [1] exploration came up with a fact that $30 \%$ of injured labors were hospitalized due to accidents in the industrial workplace. The majority of accidents related to hands and fingers which need to be treated medically. Leather is one of materials manufactured for gloves, which can be used for general or specific purposes of task. In general, leather gloves are worn to cover labor's hands and fingers from any possibilities impact from potential risks [2]. One of industrial activities that economically benefit to nation's income is metal casting operation. According to Novianto [3], metal casting is a technique where the metal is melted in a furnace and then poured into a mold to shape the desired metal product. Since metal casting involves heat to melt the metal, thermal risk is a major concern for labors in metal casting task. Leather gloves, as personal protective equipment, need to be manufactured that can prevent the workers from burn injured.

Previous studies explored the characteristic of leather when it is exposed to fire or flame. Researchers had investigated the 
flame-resistant of leather after treated with a process in the leather manufacturing, such as in tanning [4], retanning [5], fatliquoring [6], and finishing process [7]. Furthermore, Wuyong et al. [4] revealed that the untanned hide/skin was resistant to fire. However, the addition of flame retardant into the manufacturing of finished leather, especially in fatliquoring and finishing process, has not been evaluated. The study aimed to evaluate the effect of flame retardant addition on finished leather's physical and mechanical properties for a specific article, i.e. working gloves. Thus, the article could give benefit to the users for specific industrial task, especially metal casting workers.

\section{MATERIALS AND METHODS}

\section{Materials}

The research used pickled cattle hides as main material, obtained from Leather Tanneries Industrial Cluster of Magetan (LIK Magetan). The chemicals used in the beamhouse operation consisted of sodium chloride, formic acid, sodium bicarbonate, chromium basis sulfate Chromosal B from Lanxess, Teepol wetting agent, synthetic tanning agent Novaltan PF from Zschimmer \& Schwarz, Chromitan from BASF, and Tanigan PAK, Retingan R7, Tanigan XO, RP2 from Lanxess, sodium formate, levelling agent Sincal MS from Zschimmer \& Schwarz, leather's dyestuff, fatliquors Pellan 802 from Pulcra Chemicals, Cutapol WK from Dr. Bohme, Lipoderm LA and Derminol SPE from Stahl, commercial liquid-base flame retardant, and anti-mold Preventol from Lanxess. The chemicals used in finishing process were penetrator, urethane resin, acrylic resin, protein binder, filling agent, pigment, solvent lacquer, slip agent, and thinner solution. All chemicals were procured from leather chemical distributor (UD. Karyanti) in Yogyakarta.

All processes were conducted in the research laboratory with several equipment, i.e. stainless steel rotating tanning drum, plastic jar, Baume meter, $5 \mathrm{~kg}$ digital scale (Camry), $300 \mathrm{~kg}$ mechanical scale, 2 lt plastic measuring cup, wooden stirrer, leather shaving machine, toggle drying unit, staking vibration machine, stainless steel spray gun (Meiji), air compressor (Swan), and leather press machine (Mostardini).

\section{Methods}

\section{Beamhouse operation process}

Beamhouse operation is a process which consists of several steps to convert fresh or preserved skins/hides into crust leather. According to Mustakim et al. [8], leather tanning process is devided into three stages, i.e. pre-tanning, tanning, and post tanning. Since the study used pickled cattle-hides as raw material, the processing stages in this study followed the protocol of Wiryodiningrat et al. [9] with modification. The pre-tanning stage was eliminated and started from re-pickling, and followed by tanning, neutralization, retanning, dyeing, and fatliquoring. The study emphasized on the addition of flame retardant in the fatliquoring during the beamhouse operation.

The beamhouse operation process started with the preparation of pickled cattle-hides for chrome tanning. The hides were conditioned into $\mathrm{pH} 2.8-3$ with formic acid solution. After the hides have reached the $\mathrm{pH}$, the tanning were conducted by using $6 \%$ of chromium basis sulfate and run in a rotating drum for 4 hours. The process was followed by basification to reach the $\mathrm{pH}$ of the hides at 3.5 and then left overnight. The tanned-leather, called wet blue, were, then, taken out from the drum to be aged for one night. The process was continued into post-tanning process which comprised wetting back, re-chroming, neutralization, retanning, dyeing, fatliquoring, and fixing. Wetting back was a process to convert the leather from dry state, as a result of aging, to wet state with the assistance of water and wetting agent. Re-chroming process was done by adding Novaltan PF, syntan chrome, Lipoderm LA, sodium bicarbonate. The final check for re-chroming process was to reach the $\mathrm{pH}$ at 3.8. Neutralization was conducted to condition the leather towards neutral condition (pH $5.8-6.0$ ). The chemicals used in neutralization process were sodium formate, Tanigan PAK, and sodium bicarbonate. Then, retanning agent, i.e. 
Retingan R7, Tannigan XO, and RP2 were prepared for retanning process, which the process needed 60 minutes time of run in a rotating drum. The post-tanning process was ended with dyeing and fatliquoring process. The flame retardant was added $(2 \%, 4 \%$, and $6 \% \mathrm{w} / \mathrm{w}$ ) in the fatliquoring after the addition of fatliquors. It took 30 minutes of running time for the flame retardant addition in the process.

\section{Finishing process}

Finishing process is an action applied to crust leather to enhance the quality of the leather and make the leather aesthetically appealing. The process related to covering the upper surface of the leather with specific chemicals. The surface was coated in three stages by using an air-compressed spray gun. The coating sequence indicates the coating application which each of application has different function. The first stage was applied as the base coat, the second as the pigmenting coat, and the third as the top coat [10]. The finishing formula followed the procedure in Table 1.

\section{Physical-mechanical properties analysis}

The analysis of the finished leather focused on physical and mechanical properties. Physical properties covered shrinkage percentage, thickness, and rub fastness (dry/wet basis). Meanwhile, tensile strength and elongation at break were the testing to evaluate the leather properties mechanically. The shrinkage percentage of the leather was measured with Indonesian standard SNI 0234:2009 method [11]. SNI 06-7128-2005 [12] and SNI 06-0996-1989 [13] were referred to evaluate the thickness and rub fastness of the leather, respectively. Furthermore, tensile strength and elongation at break were evaluated according to SNI 06-1795-1990 [14].

\section{Research design}

Descriptive analysis were applied in this study. Jatmiko et al. [15] suggested that descriptive analysis provides detail description of an issue. This study explored different level of commercial flame retardant addition in fatliquoring and finishing process during the experiment. Table 2 describes the sample identification of this research. In fatliquoring, the process applied the flame retardant at different percentage, i.e. $2 \%, 4 \%$, and $6 \%$ $(w / w)$. Meanwhile, the addition of the flame retardant in the finishing process was 100 parts, 200 parts, and 300 parts of $1000 \mathrm{ml}$ solution. A manufacturing of finished leather without the addition of the flame retardant was conducted as the control of treatments. All treatments were replicated 6 times

\section{RESULTS}

The study evaluated several parameters which represented the physical-mechanical

Table 1. Finishing process procedure.

\begin{tabular}{|c|c|c|c|c|}
\hline \multirow{2}{*}{ Chemicals } & \multicolumn{3}{|c|}{ Stage (parts) } & \multirow{2}{*}{ Procedure } \\
\hline & A & B & $\mathrm{C}$ & \\
\hline Flame retardant & $100 / 200 / 300$ & & & A. Sprayed 2x, pressed \\
\hline Penetrator & 50 & 20 & & B. Sprayed 2-3 x (evenly) \\
\hline Water & 850 & 450 & & C. Sprayed, pressed $\left(90{ }^{\circ} \mathrm{C}, 200\right.$ \\
\hline Urethane resin & & 75 & & bar, 4-5 sec.) \\
\hline Acrylic resin & & 200 & & \\
\hline Protein binder & & 75 & & \\
\hline Wax & & 25 & & \\
\hline Pigment & & 150 & & \\
\hline Solvent lacquer & & & 200 & \\
\hline Slip agent & & & 10 & \\
\hline Thinner & & & 800 & \\
\hline
\end{tabular}




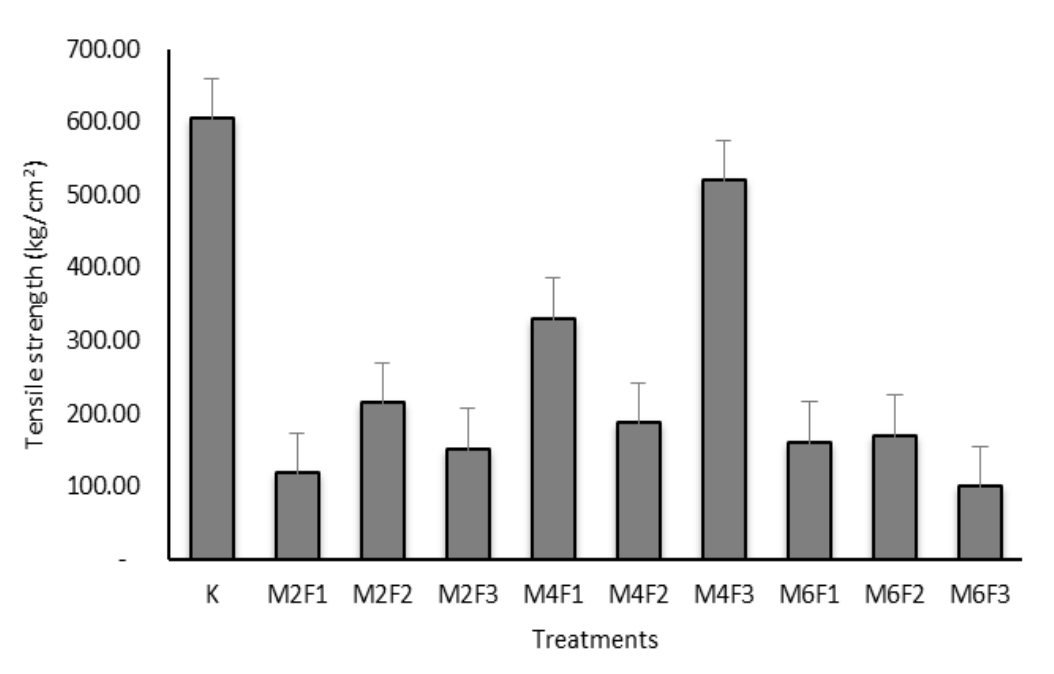

Figure 1. The tensile strength of the finished leather

properties of the finished leather, i.e. thickness, shrinkage percentage, rub fastness, tensile strength, and elongation at break. Table 3 depicts the physical quality of the finished leather after the addition of the flame retardant. A variation in thickness happened on the resulted leather where the range of thickness was at $0.71 \pm 0.04$ to $1.01 \pm 0.04 \mathrm{~mm}$. Meanwhile, the rub fastness value of the finished leather showed no variation where the samples had the same rate, 5 at dry basis and $4 / 5$ at wet basis. Shrinkage percentage indicates the stability of leather fibers in hydrothermal condition. Good quality of leather should not be shrunk more than $10 \%$ compared to its initial size. The lowest shrinkage percentage was reached at $7.65 \pm 1.42 \%$, and the highest shrinkage percentage was up to $11.60 \pm 0.89 \%$. The lowest leather's shrinkage percentage represents the best quality of leather.

Further evaluation was conducted to assess the quality of the finished leather. Figure 1 provides the tensile strength of the finished leather's sample with all variations of treatment. It can be seen from the graph that the samples with treatments resulted lower tensile strength than the control had $\left(604.89 \pm 29.96 \mathrm{~kg} / \mathrm{cm}^{2}\right)$. The highest tensile strength was reached by the sample which was added with $4 \%$ and 300 parts of the flame retardant $\left(520.48 \pm 13.79 \mathrm{~kg} / \mathrm{cm}^{2}\right)$. However, the tensile properties of the samples had different trend. The Indonesian standard required a minimum of tensile strength value at 175 $\mathrm{kg} / \mathrm{cm}^{2}$ for working glove made from chrome-tanned cow-hide leather [16].

An investigation on mechanical properties of leather also discloses the elongation of leather, as a parameter, in addition to tensile strength. Figure 2 indicates that the addition of flame retardant created negative trend on the elongation of the leather. More parts of flame retardant in finishing process decreased the elongation of the resulted leather. A steady decrease was also observed on the addition of flame retardant in fatliquoring, where the addition of $2 \%, 4 \%$, and $6 \%$ flame retardant with 200 parts flame retardant, in finishing process,

Table 2. Sample identification

\begin{tabular}{ccccc}
\hline \multirow{2}{*}{ Flame retardant addition } & & \multicolumn{3}{c}{ In the finishing process } \\
\cline { 3 - 5 } & & 100 parts & 200 parts & 300 parts \\
\hline \multirow{3}{*}{ In the fatliquoring process } & $4 \%$ & M2F1 & M2F2 & M2F3 \\
& $6 \%$ & M6F1 & M4F2 & M4F3 \\
\hline Control & & K & M6F3 \\
\hline
\end{tabular}




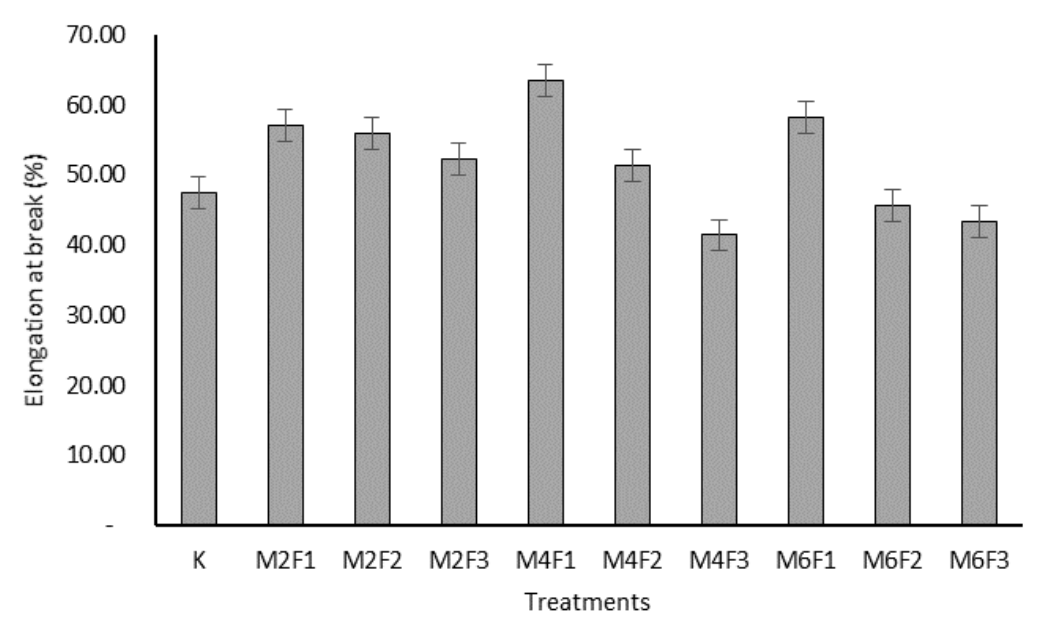

Figure 2. The finished leather's elongation at break.

tended to decrease the elongation at $55.98 \pm 2.79 \%$, $51.30 \pm 4.67 \%$, and $45.67 \pm 2.87 \%$, respectively. The study exhibited a different trend between tensile strength and elongation at break. Indonesian national standard [16] required cow leather working gloves with thickness $1.0-2.0 \mathrm{~mm}$, maximum $10 \%$ of shrinkage, unfaded on wet-basis rub fastness, slightly faded on dry-basis rub fastness, minimum $175 \mathrm{~kg} / \mathrm{cm}^{2}$ of tensile strength, and minimum $50 \%$ of leather's elongation at break. Thus, the resulted leather with the addition of $4 \%(\mathrm{w} / \mathrm{w})$ flame retardant in fatliquoring process could provide finished leather with better properties, which has the highest tensile strength, the lowest shrinkage percentage, a good fastness property, acceptable elongation and thickness.

\section{DISCUSSION}

\section{Physical properties of the finished leather}

One of practical ways to assess the quality of finished leather is through observing the physical properties. Most of the evaluation is based on the requirement standard for specific article. As revealed in Table 3, the addition of flame retardant in fatliquoring exhibits linear trend compared to that in finishing process. A negative trend in leather thickness is exposed when the sum of flame retardant was mounted during fatliqouring in beamhouse process. The thickness was gradually decrease It promotes new perspective, as it contradicts with the findings of Zan et al. [17], where more flame retardant added in the process made the

Table 3. The physical properties of the finished leather

\begin{tabular}{ccccc}
\hline \multirow{2}{*}{ Sample } & Thickness $(\mathrm{mm})$ & Shrinkage percentage $(\%)$ & \multicolumn{2}{c}{ Rub fastness } \\
\cline { 4 - 5 } & & & Dry & Wet \\
\hline K & $0.86 \pm 0.04$ & $11.60 \pm 0.89$ & 5 & $4 / 5$ \\
M2F1 & $0.93 \pm 0.04$ & $11.18 \pm 1.25$ & 5 & $4 / 5$ \\
M2F2 & $1.01 \pm 0.04$ & $9.84 \pm 1.15$ & 5 & $4 / 5$ \\
M2F3 & $0.93 \pm 0.02$ & $9.48 \pm 1.87$ & 5 & $4 / 5$ \\
M4F1 & $0.99 \pm 0.02$ & $10.48 \pm 0.95$ & 5 & $4 / 5$ \\
M4F2 & $0.95 \pm 0.01$ & $9.91 \pm 0.79$ & 5 & $4 / 5$ \\
M4F3 & $0.66 \pm 0.03$ & $7.65 \pm 1.42$ & 5 & $4 / 5$ \\
M6F1 & $0.71 \pm 0.04$ & $13.03 \pm 1.19$ & 5 & $4 / 5$ \\
M6F2 & $0.74 \pm 0.01$ & $11.25 \pm 0.63$ & 5 & $4 / 5$ \\
M6F3 & $0.76 \pm 0.02$ & $10.06 \pm 1.17$ & 5 & $4 / 5$ \\
\hline
\end{tabular}


leather thicker, due to the molecular weight of the flame retardant. The discrepancy on thickness might happened due to mechanical actions during the manufacturing of the finished leather, such as shaving and pressing. Meanwhile, the rub fastness value of the finished leather shows no variation where the samples have the same rate, 5 at dry basis and $4 / 5$ at wet basis. The rate at 5 implies that there is no discoloration and rate $4 / 5$ points out a slight discoloration on the surface [10]. The flame retardant seems to blend and covers the leather surface evenly. The rub fastness rate, at dry basis, indicates that the pigment is attached firmly, which can avoid the discoloration. However, the rub fastness at wet basis seems to expose the fact that the discoloration is slightly happened. According to Shabbir et al. [18], good fastness properties related to coordination bonding among substances in the coating solution. Thus, the study shows that the flame retardant could create a strong bonding with other substances in the finishing solution to produce a finished leather with excellent fastness properties.

The most important parameter to evaluate the physical quality of finished leather is shrinkage temperature. The stability of pelt against thermal exposure is an indicator of the tanning agent penetration into collagen fiber. The deformation of pelt is observed to figure out its stability against thermal in aqueous medium [19]. The finished leather's shrinkage reflects the bonding between the tanning agent and collagen fiber. The addition of flame retardant seems to drop off the shrinkage percentage. Initially, it is estimated that the collagen fibers reacts to the presence of the flame retardant. As a result, the addition of the flame retardant succeed to minimize the shrinkage percentage of the finished leather. Indonesian Board of Standardization suggested that maximum shrinkage percentage for chrome-tanned leather working glove were $10 \%$ [16].

\section{Mechanical properties of the finished leather}

The leather tanning process modifies the collagen fiber of hides/skins to be more compact and has better condition in term of tensile properties. As explained by $\mathrm{Wu}$ et al.
[20], tensile properties correlated with collagen fiber condition, in addition to type of tanning process. Tensile strength is one of mechanical properties that significant to evaluate the leather's quality. Tensile property represents the strength of linking between collagen fibers and tanning agent. Furthermore, beamhouse process and finishing process influence the resulted leather's elongation. Modification of collagen fibers during liming and bating have an important role to determine the elongation of the crust leather as a result of beamhouse operation process. Meanwhile, toggling and staking could influence the elongation of the finished leather. [21]. Meanwhile, Li et al. [22] suggested that tensile properties related to the humidity of leather as a result of leather making process.

An indication shows that the addition of flame retardant made the leather less moist compared to the control, especially after beamhouse process. The addition of flame retardant made the resulted leather more rigid than those without flame retardant addition. The condition was similar to the study of Sanchez-Olivares et al. [23] who then assumed that the phenomena was caused by the interaction of the flame retardant substance with the fibrils in creating a crosslinking action, thus strengthened the fiber's bond. Tensile property is the opposite of elongation, where higher tensile will indicate that the leather is hard to extend. The addition of the flame retardant in fatliquoring seems to deliver better properties for the resulted leather, in term of tensile property and elongation, compared to those in finishing process. The addition of flame retardant reveals different result when it is done in fatliquoring or in finishing process. It might be due to the nature of leather fatliquoring process, where fatliquoring agent and liquid-base flame retardant are blended, could improve the mechanical properties of leather [24] [25].

\section{CONCLUSION}

The application of flame retardant provides new perspective, particularly, in physical and mechanical quality of finished 
leather for working glove. Furthermore, its application in leather making process makes an opportunity for leather tanneries to produce leather working glove which meet the required standard. Beamhouse operation could provide ideal condition to ensure the penetration of flame retardant into the collagen fibers. The interaction between the flame retardant and the fibers, creates the desired physical-mechanical properties for working glove leather article. The use of $4 \%$ $(\mathrm{w} / \mathrm{w})$ flame retardant in fatliquoring is suggested to be the best formulation to produce cattle hide leather working glove.

\section{CONFLICT OF INTEREST}

The authors declare no conflict of interest with any financial organization regarding the material discussed in the manuscript. The funders had no role in the design of the study; in the collection, analyses, or interpretation of data; in the writing of the manuscript, or in the decision to publish the results.

\section{ACKNOWLEDGMENTS}

The research was funded by the Ministry of Industry through the Center for Leather, Rubber and Plastics research and development project fund No. 1866.007.073. The authors would like to acknowledge Ir. Widari and Thomas Tukirin, S.T.P. for their advice and assistance during the research.

\section{REFERENCES}

1. Dianat, I., C. M. Haslegrave, and A. W. Stedmon. 2012. Methodology for evaluating gloves in relation to the effects on hand performance capabilities: A literature review. Ergonomics. 55:1429-1451.

doi:10.1080/00140139.2012.708058.

2. Batra, S., L. A. Bronkema, M. J. Wang, and R. R. Bishu. 1994. Glove attributes: Can they predict performance? Int. J. Ind. Ergon.

14:201-209. doi:10.1016/0169-8141(94)90096-5.

3. Novianto, N. D. 2015. Penggunaan alat pelindung diri (APD) pada pekerja pengecoran logam PT. Sinar Semesta (Studi kasus tentang perilaku penggunaan alat pelindung diri (APD) ditinjau dari pengetahuan terhadap potensi bahaya dan resiko kecelakaan kerja pada pekerja pengecoran 1. J. Kesehat. Masy. 3:417-428.

4. Wuyong, C., L. Chunxia, G. Ying, and H. Zan. 2007. Influence of tanning on the flammability of leather. J. Soc. Leather Technol. Chem. 91:159-161.

5. Zan, H., L. Lixin, L. Yinsheng, L. Yunzhou, and C. Wuyong. 2005. Influence of retanning on the flammability of leather. China Leather. 34:1-4.

6. Huang, Z., L. Lixin, W. Chen, and H. Gui. 2006. Influence of fatliquoring on flammability of leather. J. Soc. Leather Technol. Chem. 90:155-158.

7. Ying G, Wuyong $C$, Jiping $C$, and Haibin G. 2007. Influence of finishing on the flammability of leather. J. Soc. Leather Technol. Chem., 91 (5), 208-211.

8. Mustakim, Widati AS, Al-Awwaly KU, and Umaya L. 2017. Pengaruh presentase kuning telur itik dan asam formiat dalam proses peminyakan terhadap kekuatan fisik kulit ayam pedaging sama khrom. J. Ilmu dan Teknol. Has. Ternak, 12 (1), 29-38. doi:10.21776/ub.jitek.2017.012.01.5.

9. Wiryodiningrat, S., R. S. Murti, and I. F. Pahlawan. 2012. Pembuatan kulit jok ramah lingkungan untuk otomotif. Maj. Kulit, Karet dan Plast. 28:9-17. doi:10.20543/mkkp.v28i1.200.

10. Griyanitasari, G., E. Kasmudjiastuti E, and B. Pidhatika. 2017. Pengaruh variasi pigmen untuk lapisan dasar (base coat) pada proses finishing terhadap sifat fisik kulit sapi. Bul. Peternak. 41:307-318. doi:10.21059/buletinpeternak.v41i3.16649.

11. BSN. 2009. SNI 0234:2009 Kulit bagian atas alas kaki - Kulit boks. Badan Standardisasi 
Nasional, Jakarta.

12. BSN. 2005. SNI 06-7128-2005 Cara uji pengukuran tebal kulit jadi. Badan Standardisasi Nasional, Jakarta.

13. BSN. 1989. SNI 06-0996-1989 Cara uji ketahanan gosok cat tutup untuk kulit jadi dengan alat crock meter. Badan Standardisasi Nasional, Jakarta.

14. BSN. 1992. SNI 06-1795-1990: Cara uji kekuatan tarik dan kemuluran kulit. Badan Standardisasi Nasional, Jakarta.

15. Jatmiko W, Santoso HB, Purbarani SC, Syulistyo AR, Purnomo DMJ, Firmansyah D, Yusuf M, dan Laili NA. (2015). Panduan penulisan artikel ilmiah. UI Press, Jakarta.

16. BSN. 1989. SNI 06-0485-1989 Kulit sarung tangan samak krom dari kulit sapi untuk kerja berat. Badan Standardisasi Nasional, Jakarta.

17. Zan, H., L. Lixin, W. Yinghong, L. Yunzhou, and C. Wuyong. 2005. Performance of flame retardants on leather. J. Soc. Leather Technol. Chem. 89:225-231.

18. Shabbir, M., S. U. Islam, M. N. Bukhari, L. J. Rather, M. A. Khan, and F. Mohammad. 2017. Application of Terminalia chebula natural dye on wool fiber - Evaluation of color and fastness properties. Text. Cloth. Sustain. 2:1-9. doi:10.1186/s40689-016-0011-8.

19. Onem, E., A. Yorgancioglu, H. A. Karavana, O. and Yilmaz. 2017. Comparison of different tanning agents on the stabilization of collagen via differential scanning calorimetry. J. Therm. Anal. Calorim. 129:615-622. doi:10.1007/s10973-017-6175-x.

20. Wu, C., W. Zhang, X. Liao, Y. Zeng, and B. Shi. 2014. Transposition of chrome tanning in leather making. J. Am. Leather Chem. Assoc. 109:176-183.

21.Pahlawan, I. F. and E. Kasmudjiastuti.
2012. Pengaruh jumlah minyak terhadap sifat fisis kulit ikan nila (Oreochromis niloticus) untuk bagian atas sepatu. Maj. Kulit, Karet, dan Plast., 2:105-111. doi:10.20543/mkkp.v28i2.113.

22. Li, Z., D. Paudecerf, and J. Yang. 2009. Mechanical behaviour of natural cow leather in tension. Acta Mech. Solida Sin. 22:37-44. doi:10.1016/S0894-9166(09)60088-4.

23. Sanchez-Olivares, G., A. Sanchez-Solis, F. Calderas, L. Medina-Torres, O. Manero, A. Blasio, Di, and J. Alongi. 2014. Sodium montmorillonite effect on the morphology, thermal, flame retardant and mechanical properties of semi-finished leather. Appl. Clay Sci. 102:254-260. doi:10.1016/j.clay.2014.10.007.

24. John, G. 1996. Possible defects in leather production: Definitions, causes, consequences, remedies and types of leather. 1st ed. Lapertheim, Germany.

25. Sizeland, K. H., G. Holmes, R. I. Edmonds, N. Kirby, A. Hawley, S. T. Mudie, and R. G. Haverkamp. 2015. Fatliquor effects on collagen fibril orientation and D-spacing in leather during tensile strain. J. Am. Leather Chem. Assoc. 110:355-362. 